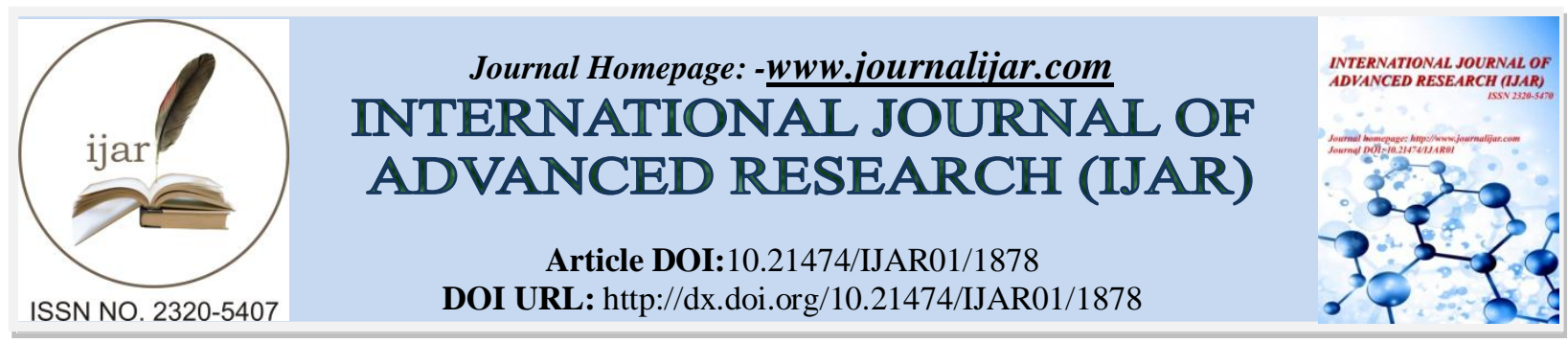

RESEARCH ARTICLE

\title{
ISOLATION AND IDENTIFICATION OF PATULIN TOXIGENIC FUNGI ASSOCIATED WITH DATE FRUITS IN IRAQ.
}

\section{M.sc. Mohammad Jaffar Khadom ${ }^{1}$, Dr.Hadi M. Aboud ${ }^{1}$, Dr. Shatha Ali Shafiq ${ }^{2}$ and M.sc. SamiJabbar Ismael $^{2}$.}

1. Directorate of Agricultural Researches, Ministry of Science and Technology.

2. Mustansiriyah university -College of Science, Department of Biology.

\section{Manuscript Info}

Manuscript History

Received: 12 August 2016

Final Accepted: 16 September 2016

Published: October 2016

\section{Abstract}

The results of Patulin detection in 6 samples of Date fruits collected from different locations of Iraq revealed that all tested samples were contaminated with PAT, samples E, A and B showed the highest contamination levels which recorded $(514.4,367.6$ and 264.9$) \mu \mathrm{g} / \mathrm{ml}$, while the samples D showed the lowest contamination level which recorded (84.4) $\mu \mathrm{g} / \mathrm{ml}$. The results also showed that Aspergillus spp. recorded the high percentage of occurrence $100 \%$ in A,C,D and E samples, while it was 31.25 and $63.64 \%$ in samples F and B respectively. Also the occurrence percentage of Penicillium spp. rated from 0.0 to $68.75 \%$, sample (A,C,D and E) recorded the lowest percentage of occurrence $0.0 \%$ while sample $(\mathrm{F})$ recorded the highest percentage $68.75 \%$.

Copy Right, IJAR, 2016,. All rights reserved.

\section{Introduction:-}

Mycotoxins are natural secondary metabolites produce by microorganisms of kingdom fungi, commonly known as molds that are growing on agricultural commodities and have adverse effects on human, animals and crops, result in health and environmental threat beside economic losses (Richard , 2007). More than 500 types of mycotoxins have been identified to present, which include the most commonly mycotoxins associated with food and feed that may be concern to consumer food safety : Aflatoxin, Ochratoxin A, Patulin and Trichothesences (Maganet al.,2004) .

Toxigenic fungi may grow under certain limit climatic conditions to produce mycotoxins on any solid or liquid media support as soon as nutritional substances and moisture are present, hence the wide variety of contaminated foodstuff substrates are subjected to spoilage as a results of fungal growth. Natural occurrence of mycotoxins are found as natural contaminants in many feedstuffs including cereals, vegetables, fruits, oil seeds and foods consisting of or manufactured from, these products and intended for human or animal consumption (Abad et al., 2002). Mycotoxins are highly toxic compounds of small molecular weight and quite stable molecules which are extremely difficult to remove or eradicate, and which enter the food chain while keeping their toxic properties (Reddy et al., 2010).

Among the most important mycotoxins was Patulin ( $\beta$ - unsaturated lactone)which was soluble in water and most polar organic solvents - soluble, produced by a number of fungal species belonging to the genera Penicillium , 
Aspergillus , Byssochlomys and Pacelomyces (Druschet al., 2007). The main producer of PAT is the blue mold Penicilliumexpansum, which is considered as a wound pathogen (Lai et al.,2000). It is usually associated with fruits and vegetables especially in apple and apple products (Ritieni , 2003). PAT was first isolated as an antimicrobial active principle during 1940s from Penicilliumgriseofulvum, during the 1960s, PAT was reclassified as a mycotoxin which was toxic to both plants and animals (Andersen et al., 2004).

Dates one of the most important fruits produces in Iraq. Date exposed to fungal contamination in fielded and during transporting and storage, no study was conducted regarding its contamination with toxigenic fungi in general and specially those producing Patulin so, the aim of this study to isolate and identify of fungi associated with storage dates and detect its contamination with Patulin.

\section{Materials and Methods:-}

\section{Samples Collection:-}

Six samples of date were collected from different local markets at Baghdad from 5/3/2015 to 20/5/2015.Sampleswere named according to date palm cultivar also samples collection were symbol as shown in (Table1).Each sample was placed in black plastic bags and the information of the location and time in collection was recorded. The samples transported to the laboratory for microbial analysis.

Table1:- Sample symbol and type of date fruits.

\begin{tabular}{|c|c|c|}
\hline Date Palm cultivar & Location & Samplesymbol \\
\hline Zahdi & Bab al- muazam & A \\
\hline Decal & Al-zaafrania & C \\
\hline Breem & Baghdad al- jdeeda & D \\
\hline Barban & Al-shaab & E \\
\hline Jeesip & Al-sadr city & F \\
\hline Madjool & Al-khadmia & \\
\hline
\end{tabular}

\section{Isolation and Identification of Fungi:-}

Twenty grams of each sample was taken randomly cut in small pieces $(0.5 \mathrm{~cm})$, surface sterilized with Sodium Hypochlorite solution (1\%) for $2 \mathrm{~min}$. and rinsed twice with sterilized distilled water. Samples were dried with sterile filter paper, cultured on Potato Dextrose Agar (PDA) plates supplemented with antibiotic (Chloramphenicol) in concentration $100 \mu \mathrm{g} / \mathrm{ml}$. Three pieces in each plate, each replicate has 3 plates and each sample triplicated, incubated for $5-7$ days at $25^{\circ}$ C.Fungal growth on dates were sub-cultured by transferring a small mycelia plugs from the colony margins. Pure culture was obtained by sub-culturing many times then identified on the basis of their morphological characters by observing colony feature (colony and texture) and microscopically by staining with lactophenol cotton blue and observe under microscope for the conidia, conidiophores and arrangement of spores, the fungi were identified and classified depended on taxonomic keys (Raper and Fennell,1965; Simmons , 1967), the percentage of occurance and frequency of isolation to each isolated fungal genus and species were calculated according to the following formula:-

$\%$ occurrence of Genus $=($ colonies number of genus $) /($ total number of genera colonies $) \times 100$

$\%$ occurrence of species $=($ colonies number of species $) /($ total number of species colonies $) \times 100$

$\%$ frequency of Genus $=($ Number of genus appearance in the sample) $/$ (total number of the genera appearance $) \times 100$

$\%$ frequency of species $=($ Number of species appearance in the sample $) /($ total number of the species appearance) $\times 100$

\section{Detection of Patulin in Date Fruits:-}

The method described by (Ismael , 2015) in the detection of PAT in dried fruits collected samples was carried out as following :-

1. Fifty grams of each sample of the date fruit was weighted and soaked with $100 \mathrm{ml}$ distilled water and left for 24 hours then blended by electric blender for 2 min.

2. The mixture was filtered using medical sterile gauze.

3. Ten $\mathrm{ml}$ of the filtrate was transferred to a separating funnel, $20 \mathrm{ml}$ Chloroform was added then shacked for 10 $\min$. 
4. The top layer of chloroform was filtered through a bed of anhydrous Sodium Sulphate (Na2So4) and evaporated using rotary evaporator at $45^{\circ} \mathrm{C}$.

5. One $\mathrm{ml}$ of acetonitrile was added to extract then filtered by Millipore filters $(0.45 \mu \mathrm{m})$ and collection in small tube specific to HPLC.

6. Using Shimadzo HPLC system Model LC-2010A HT device, with column 5u Spherical C18 (250* $4.6 \mathrm{~mm})$.

7. 0.2 microliter of filtrate was injected in HPLC device under U.V. Light at a wave length of $(267 \mathrm{~nm})$, with determination of Rotation time (RT) was 4 minute, the flow rate $0.7 \mathrm{~mL} / \mathrm{min}$ and mobile phase acetonitrile / D.D. Water (5:95) .

8. The amount of PAT was estimated in comparison with standard PAT through the following formula (EEC, 1992 )

9. PAT concentration $=($ Peak area of sample $) /($ Peak area of standard $) \times$ Standard concentration.

\section{Results and Discussion:-}

Isolation and Identification of Fungi associated with Date Fruits:-

The results of isolation and identification of fungi associated with 6 samples of dates fruits showed that the number of fungal genera and species isolated, was varied in the percentage of occurrence and frequency of isolation according to sample kind and the location of collection samples (Table 1), results of isolation and identification of fungi associated with 6 samples of date fruit showed the isolation of Aspergllusspp. and Pencillium spp. with clear variation in the occurrence and frequency of isolation (Table. 2). The genus Aspergillus spp. was the highest occurrence fungus ranged from $31.25 \%$ to $100 \%$. Samples A,C,D and E recorded the highest percentage of occurrence in $100 \%$. The lowest percentage of occurrence were $31.25 \%$ and $63.64 \%$ which recorded by FandB respectively. The next genus was Penicillium spp. with occurrence ranged from 36.36 to $68.75 \%$. The highest percentage of occurrence recorded by sample F $68.75 \%$, while the lowest percentage of occurrence $36.36 \%$ recorded by sample B $68.75 \%$.

Regarding fungal species Aspergillusniger recorded the highest percentage of occurrence $100 \%$ in samples A,C,D and E, while the lowest percentage of occurrence recorded by sample F $25 \%$. The next fungal species was Aspergillusflavus which recorded percentage of occurrence $8.33 \%$ in one sample A, followed by the species Aspergillusfumigatus which recorded a percentage of occurrence $6.25 \%$ in sample F.

Regarding Penicillium species, only P.expansum was recorded with the percentage of occurrence ranged from 36.36 to $68.75 \%$, the highest percentage $68.75 \%$ recorded in sample $\mathrm{F}$ and the lowest percentage of occurrence recorded by sample B $36.36 \%$.

Table 2:-The percentage of fungi that associated with Date fruits.

\begin{tabular}{|c|c|c|c|c|c|}
\hline Samples & Type of Fungi & $\begin{array}{c}\text { Occurance of } \\
\text { Genus }\end{array}$ & $\begin{array}{c}\text { Occurance of } \\
\text { Species }\end{array}$ & $\begin{array}{c}\text { Frequency of } \\
\text { Genus }\end{array}$ & $\begin{array}{c}\text { Frequency of } \\
\text { Species }\end{array}$ \\
\hline $\mathbf{A}$ & $\begin{array}{c}\text { Aspergillusspp. } \\
\text { A.nigar } \\
\text { A.flavus }\end{array}$ & 100 & $\begin{array}{c}91.67 \\
8.33\end{array}$ & 100 & $\begin{array}{l}83.33 \\
16.67 \\
\end{array}$ \\
\hline B & $\begin{array}{c}\text { Aspergillusspp. } \\
\text { A.nigar } \\
\text { Pencilliumspp. } \\
\text { P.expansum }\end{array}$ & \begin{tabular}{r|}
63.64 \\
36.36
\end{tabular} & $\begin{array}{r}63.64 \\
36.36\end{array}$ & $\begin{array}{l}50 \\
50\end{array}$ & $\begin{array}{l}50 \\
50\end{array}$ \\
\hline $\mathbf{C}$ & $\begin{array}{c}\text { Aspergillusspp. } \\
\text { A.nigar }\end{array}$ & 100 & 100 & 100 & 100 \\
\hline D & $\begin{array}{c}\text { Aspergillusspp. } \\
\text { A.nigar }\end{array}$ & 100 & 100 & 100 & 100 \\
\hline $\mathbf{E}$ & $\begin{array}{c}\text { Aspergillusspp. } \\
\text { A.nigar }\end{array}$ & 100 & 100 & 100 & 100 \\
\hline $\mathbf{F}$ & $\begin{array}{c}\text { Aspergillusspp. } \\
\text { A.nigar } \\
\text { A.fumigates } \\
\text { Pencilliumspp. } \\
\text { P.expansum } \\
\end{array}$ & $\begin{array}{l}31.25 \\
68.75\end{array}$ & $\begin{array}{c}25 \\
6.25 \\
68.75 \\
\end{array}$ & $\begin{array}{r}66.67 \\
33.33\end{array}$ & $\begin{array}{c}50 \\
16.67 \\
\\
33.33 \\
\end{array}$ \\
\hline
\end{tabular}


In samplesA,C,D and E showed 100\% occurrence for the fungus Aspergillus spp. and this might be return to saprophytic nature of this genus beside it closely associated with agriculture and other human activities that make nutrients available to this highly competitive fungus. Also contamination reason may be due to bad storage conditions. It has been proven that high temperatures to more than $37^{\circ} \mathrm{C}$ makes the genus of Aspergillus more predominate and this was confirmed by (Valero et al., 2005).Aspergillusspp. possess the ability to grow will at a high osmotic concentrations (high sugar, salt, etc.) exists, in addition to the colonies of genus Aspergilluswere present on the berry skin from fruit setting and increase in amount from early variation to harvest, with a peak at ripening; however the incidence of colonized berries was highly related to climatic conditions during the ripening stage and to the geographical location(Visconti et al. 2008 ; Cozziet al., 2009). The isolated frequency of Aspergillusflavus was due to the saprophytic nature of this fungus and its ability to utilize a wide range of nutrient sources. A. flavus has a capacity to produce a large array of enzymes to support biodegradation process of complex compounds. Indeed, when substrate utilization by A. flavus in compared to obligate pathogens, A. flavus was also found to have greater capacity for growth on both complex protein substrates (elastin and mucin) and complex carbohydrate substrates (Abdullah et al., 2009).

The last recorded species belonged to the genus Aspergillus was

A. fumigatus which it appeared in some samples, the reason of its present of A.fumigatusreturned to its saprotrophic widespread in nature, it was typically found in soil and decaying organic compounds, such as compost heaps, where it played an essential role in carbon and nitrogen recycling and colonies of the fungus produce from conidiophores, although A. fumigatus occurs in areas with widely different climates and environments, the fungus was capable of growth at temperature $37^{\circ} \mathrm{C}$ and can grow at temperatures up to $50^{\circ} \mathrm{C}$, with conidia surviving at temperature $70^{\circ} \mathrm{C}$ conditions, it also regularly encounters in self-heating compost heaps. Its spores were found everywhere in the atmosphere (O'Gorman et al., 2008).

The second genus appeared in the tested samples was Pencilliumspp. and only the species P.expansum was recorded, this due to the ability of this fungus to grow on grains and other stored foods rely on their propensity to grow in low humidity and colonize rapidly by aerial dispersion while the seeds were sufficiently moist (Pitt et al. 2000).

Some species of Penicillium affect the fruits and bulbs of plants, including P. expansum (Balgrie, 2003). Penicillium species were present in the air and dust of indoor environments, such as homes and public buildings (Larous et al., 2007).

Penicilliumexpansum was a postharvest pathogen that affects number of different hosts, including some fruits such as apples, pears and cherries. The certain temperature to growP.expansum essentially starts at optimum temperature range from $15-27^{\circ} \mathrm{C}$, while some growth was still exhibited at temperatures lower and higher than this range but growth was much slower outside of this temperature range (Larouset al., 2007).

\section{Detection of PAT in Date Fruits :-}

The results of the detection of PAT in 6 samples of date fruits, using HPLC, revealed the presence of PAT in all tested samples although the concentration was varied according to kind of sample and location of collection . (Table $3)$.

The results showed that all the samples of date fruit were PAT contaminated in range from $(84.4-514.4) \mu \mathrm{g} / \mathrm{ml}$. Sample E showed the highest concentration level (514.4) $\mu \mathrm{g} / \mathrm{ml}$ followed by Awhich recorded (367.6) $\mu \mathrm{g} / \mathrm{ml}$. While sample D showed the lowest concentration level $(84.4) \mu \mathrm{g} / \mathrm{ml}$.

Table 3:-The Quantitative estimation of PAT in date fruit samples.

\begin{tabular}{|c|c|c|}
\hline Samples & Date cultivar & Concentration of PAT. $\boldsymbol{\mu g} / \mathbf{m l}$ \\
\hline A & Zahdi & $\mathbf{3 6 7 . 6}$ \\
\hline B & Decal & $\mathbf{2 6 4 . 9}$ \\
\hline C & Breem & 156.6 \\
\hline D & Barban & 84.4 \\
\hline E & Jeesip & 514.4 \\
\hline F & Madjool & 109.9 \\
\hline
\end{tabular}


The reason of low concentration of PAT in sample D might be due to good storage conditions and ventilation of dates, and suitable temperatures and humidity, on the other hand the highest concentration of PAT was recorded in sample E $514.4 \mu \mathrm{g} / \mathrm{ml}$, might be due to the suitable storage conditions for fungus grow and production of PAT ,Trucksess and Scott, (2007) found that the fungal contamination of these products, was highly effected by sorting, storage, and processing.

\section{References:-}

1. Abad, E.; Llerena, J.J.; Saulo, J.; Caixach, J. and Rivera, J. 2002. Comprehensive study on dioxin contents in binder and anti-caking agent feed additives. Chemosphere, 46, 1417-1421.

2. Abdullah, S.K. and Al-Mousawi, K.A. 2009. Incidence of Aspergillusin seeds of corn and sunflower cultivars grown in Iraq and aflatoxin-producing potential of Aspergillussection Flavi. Proc. 1st Scient. Conf. Biol. Sci. Mosul University, pp. 299-307.

3. Andersen, B., Smedsgaard, J. and Frisvad, J.C. 2004. Penicilliumexpansum: consistent production of patulin, chaetoglobosins, and other secondary metabolites in culture and their natural occurrence in fruit products. J. Agricult. Food Chem., 52, 2421-2428.

4. Balgrie, B. 2003.Taints and Off-flavours in Food. CRC Press. p. 134.

5. Cozzi, G.; Haidukowski, M. ;Perrone, G. ; Visconti, A. and Logrieco, A. 2009. Influence of Lobesiabotranafield control on black aspergilli rot and ochratoxin A contamination in grapes. Journal of Food Protection72 (4), 894-897.

6. Drusch , S. ; Kopka , S. and Kaeding , J. 2007. Stability of Patulin in a juice - like aqueous model system in the presence of ascorbic acid, food chemistry, 100 (1) : $192-197$.

7. EEC, .1992. Official Journal of the European communies.L327/54 .13.11 .92.

8. Hasan, H. A. H. 2000. Patulin and aflatoxin in brown rot lesion of apple fruits and their regulation. World Journal of Microbiology and Biotechnology, 16:607-612.

9. Ismael, S.J. 2015. Investigation for Patulin toxin producing from some fungi in dried fruits and its biological degradation.M.Sc.thesis, Al-Mustansiriya University, College of Science, Pp.38.

10. Lai, L. ;Fuh , M. and Shih, C.2000 . Detection of mycotoxinPatulin in apple juice. J. Food and Drug Analysis, 8, P:85-96.

11. Larous, L.; Handel, N.; Abood, J.K. and Ghoul, M. 2007. "The growth and production of Patulinmycotoxin by Penicilliumexpansum on apple fruits and its control by the use of propionic acid and sodium benzoate". Department of Biology, College of Science, University of Setiff. Setiff, Algeria.

12. Magan , N. ; Aldred, D. and Sanchis , V. 2004. The role of spoilage fungi in seed deterioration in: Arora , D.K. (eds.), Fungal Biotechnology in Agricultural, Food and Environmental Applications, P: 311-123.

13. O'Gorman, C.M. ;Hubert, T. F. and Paul, S. D. 2008. "Discovery of a sexual cycle in the opportunistic fungal pathogen Aspergillusfumigatus". Nature , 457 (7228) , P: 471-4.

14. Pitt, J.I.; Basílico, J.C.; Abarca, M.L.; López, C.; Basílico; Abarca and López 2000. "Mycotoxins and toxigenic fungi". Medical Mycology, 38 (vol. 1): P: 41-46.

15. Raper, K.B. and Fennell, D.I. 1965. The genusAspergillus. Williams and Wilkins Company.

16. Reddy, K.R.N.; Nurdijati, S.B. and Salleh, B. 2010 . An overview of plant-derived products on control of mycotoxigenic fungi and mycotoxins. Asian Journal of Plant Science, Vol. 9, P: 126-133.

17. Richard, J.L. 2007. "Some major mycotoxins and their mycotoxicoses — an overview". Int. J. Food Microbiol., 119 (1-2), P: 3-10.

18. Ritieni , A. 2003 .Patulin in Italian commercial apple products. Journal of Agricultural and food chemistry , 51 (21), P:6086-6090 .

19. Simmons,E.G. 1967.Typification of Alternaria,Strephyllium and Ulocladium . Mycological .59, P:67 -92.

20. Trucksess , M. W. and Scott , P. M. 2007 .Mycotoxins in botanicals and dried fruits: A review. Food Additives and Contaminants, 25(2), P: 181-192.

21. Valero A. ;Marín, S. ; Ramos, A.J. and Sanchis, V. 2005.Ochratoxin A-producing species in grapes and sundried grapes and their relation to ecophysiological factors. Letters in Applied Microbiology, 41, P:196-201.

22. Visconti A.; Perrone, G. ;Cozzi, G. and Solfrizzo, M.2008. Managing ochratoxinA risk in the grape-wine food chain. Food Additives and Contaminants, Part A, 25 (2), P:193-202. 